\title{
The Effect of Language Teaching Methods on Academic Success in Turkey
}

\author{
Burcu Ökmen ${ }^{1}$, Abdurrahman Kılıç ${ }^{1}$ \\ ${ }^{1}$ Duzce University, Turkey \\ Correspondence: Burcu Ökmen, Duzce University, Turkey.
}

Received: July 26, 2016

Accepted: August 17, 2016

Online Published: September 6, 2016

doi:10.11114/jets.v4i10.1767

URL: http://dx.doi.org/10.11114/jets.v4i10.1767

\begin{abstract}
The aim of this research is to observe the effect of language teaching methods on students' TEOG foreign language exams, the exam which is necessary to pass from secondary school to high school, administered by the Ministry of Education. The research sample consisted of 95 English teachers who taught in secondary schools in Duzce in 2013-2014, and the average scores of 8th grades students' TEOG English exams. It was conducted using the survey method and quantitative data were used. A language teaching methods scale developed by the researcher was implemented to define which methods English teachers use. It was found that there was a meaningful and positive relationship between methods and success. Also, there was a statistically significant difference in students' TEOG foreign language exam scores, depending on the language teaching method used by English teachers.
\end{abstract}

Keywords: language teaching, method, academic success

\section{Introduction}

In today's world, the most important aspect of lifelong learning and development is language, as we are experiencing the information age. Activities such as reading, writing, thinking, problem-solving, questioning, and understanding are all performed with language skills. Language is the basic tool for mental, emotional and social development. It has an important place in processes such as establishing communications, expressing emotions and thoughts, integrating with the outer world, transferring culture, and interacting with people. Language affects the characteristics of individuals, e.g., improving capacities, solving complex problems, scientific thinking, having various values, and a wider world viewpoint. This situation shows that language skills must be developed on a lifelong basis, and language development must not be limited to the education given at school. For this reason, many countries are interested in the application of new approaches and methods to develop people's language skills (Gunes, 2011).

Today, Turkey is a member of the United Nations, Council of Europe, North Atlantic Treaty Organization (NATO), the Organization for Economic Cooperation and Development, and other international institutions. As a common communication tool, these international institutions accept some nations' languages, for example, English, Chinese, Russian, Spanish, and French. Instructions such as NATO, which are important to Turkey, use English as a formal language. As Turkey has intensive communication with other countries, it is necessary to learn a foreign language so the teaching of foreign languages is therefore established in the curriculum (Demirel, 2012).

When we consider the history of foreign language teaching, we observe that the issue of how to teach a language has always been a subject of discussion. We may define foreign language teaching methods as the systems that show how students can become more active learners during language teaching, beyond being a mere compilation of rules. In other words, it is possible to claim that method in language learning is a teaching element that will help the student achieve the targets of the learning in the fastest and most reliable manner. It is a reality that there have been many learning and teaching approaches developed. However, we cannot claim that there is one single ideal method in any real sense. The methods used in foreign language teaching define the hypothetical bases of teaching. For this reason, it is necessary to know the basic rules, limits, limitations, usage, and characteristics of the selected methods (Memis \& Erdem, 2013).

Prior to this century, language teaching methodology vacillated between two types of approaches: one type of approach which focused on using a language (i.e., speaking and understanding), the other type which focused on analyzing a language (i.e., learning the grammatical rules). Both the Classical Greek and Medieval Latin periods were characterized by an emphasis on teaching people to use foreign languages (Murcia, 2013, p.1).

Actually the first teaching methodology for acquiring a foreign language was the one applied for learning Latin. 
Due to the fact that Latin was the language of education 500 years ago its study was immensely important for educated learners. The detailed study of grammar, as for example studying conjugations and declensions, doing translations and writing sample sentences was seen as central in the teaching methodology at the time. (Kamhuber, 2010, p.9)

The knowledge of language rules was taught instead of teaching using language skills. This usage and opinion started to change through the 1950s. Instead of giving knowledge about language, usage of language in daily life and communication became important. Nowadays it is common idea "Language is a social interaction tool" (Gunes, 2011).

Atraditional foreign language teaching method was used at schools during the Ottoman State, which had existed since former times when teaching was carried out with a foreign language, and at foreign schools that were built later in the Westernization process. The same traditional method was used by Turkish and foreign language teachers in the Turkish schools that were opened during the Westernization process in Turkey. Language use was not taught with this method but information was given about the rules of the language. For this reason, a certain stereotypical culture has been formed in foreign language teaching from the Ottoman State until the present day, and this method has influenced foreign language applications today. Today, it is possible to see the influences of this method when the course books and the applications in the classrooms are examined. It is possible to claim that the traditional language teaching method is beneficial for foreign language studies that are not used as a means of communication or that are far from the living language. However, it is also clear that the traditional method is not beneficial in situations where living foreign languages are used as a means of communication, interaction and learning (Isik, 2008).

It is not possible to speak of the existence of one ideal single method. The most distinctive criterion in selecting a method is the issue of the purpose of teaching the language. For example, there are differences in the methods that are used to teach languages in primary schools and secondary schools. The use of "body language" is emphasized in primary schools. "Mimics, gestures, etc." i.e. "the actual" factor comes to the forefront at this point. In secondary schools, on the other hand, "understanding" and "explaining" are carried out by sticking to one single resource, and generally sample dialogues are made use of in recordings. For this reason, "functionality" is the basic principle in the foreign language teaching approach. Language is considered, not only as an object to be examined or a topic to be worked on, but as a means of "action". Language is a tool that helps to use our body language (Ansin, 2006).

In 2012, SETA (the Foundation of Politics, Economy and Society) carried out a study with contributions from the Ministry of Youth and Sports: "The Profile of Turkey's Youth". In this study, most participants said that they did not know a foreign language. Moreover, there were significant differences among the regions in the levels of knowing a foreign language. According to that study, participants in the East Anatolian Region have a lower level of language knowledge than participants in other regions. At the same time, the level of knowing a foreign language increases in parallel with the level of education. The most common foreign language among participants is English. Germany, Arabic, Russian, and French are less well known. It is seen that lack of knowledge of a foreign language is an obstacle to the integration of young people with the world.

When we look at the foreign language curriculum in Turkey, it is seen that English is the most taught foreign language. English language training starts in primary school with two hours every week. Moreover, it is 10 hours in some high schools. Also children take English courses in private primary and pre-school institutions. In some universities, the language of instructions English. Additionally, in other universities, English is a compulsory course. Although there is English training in the long term, the language is not used as a communication tool. As long as traditional language teaching methods are used, it will be difficult to use language as a communication tool for students. Troubles with the traditional method have given rise to new approaches, methods and techniques that aim to make language learning engaging and useful (Gomleksiz \&Elald1, 2011).

It is obvious that the method used has an important function in teaching. However, before using a method, its rules and limitations must be known, and the users must also know in which classes they are going to use it and for what purposes, and they must understand its positives and negatives. It is impossible to talk about a method or technique that is influential in all fields or in every situation. The methods must be selected to reach the predefined purpose and must be organized in this direction. The selected methods must be in a structure that will ensure the consistency and integrity of the learning experiences (Yildizlar, 2013).

There are many suggestions and arguments about language teaching. Although there are a many studies of the factors that affect learning a foreign language, we could not find enough research about teaching in Turkey. The curriculum suggests to the teacher how they should teach and which methods they should use but there is no research about the usefulness and effectiveness of the methods suggested. This research focuses on language teaching and the relationship between methods and English exam scores. 
The aim of this research is to observe the relationship between language teaching methods used by teachers and academic success scores. In this context, the questions below will be answered:

1. Is there a relationship between methods used by English teachers and the TEOG foreign language exam scores?

2. Is there a statistically significant difference in students' TEOG foreign language exam scores depending on the language teaching methods used by their English teachers?

\section{Research Design and Methodology}

\subsection{Research Model}

The aim of the correlational research is to observe the relationship between variables. In this research variables are not inferred (Büyüköztürk, Çakmak, Akgün, Karadeniz, \& Demirel, 2013) so in this research correlational research was carried out and quantitative data were used.

\subsection{Participants}

In this research the criterion sampling method was used. As a criterion it was determined that teachers should work in a secondary school because TEOG is only applied to secondary school students. The research group consisted of 95 English teachers who worked in secondary schools in Duzce in the 2013-2014 academic year. It was aimed at reaching all English teachers in Duzce.

\subsection{Data Collection Tool}

A scale developed by the researcher was used to define the language teaching methods that teachers use (Okmen, 2015). The scale had 23 items and was developed to determine the language teaching methods used by English teachers. Exploratory and confirmatory factor analysis were done to define structure validity and showed that there were five factors in scale. The total variance explained by the five factors was calculated at $54.69 \%$. These factors were called Active Teaching Method, Listening Based Teaching Method, Four Basic Skills Based Method, Speaking Based Method, and Grammar Based Method. The Active Teaching Method has six items and its Cronbach Alpha reliability co-efficient is .79.The Listening Based Teaching Method has six items and its Cronbach Alpha reliability co-efficient is .53. The Four Basic Skills Focused Method has five items and its Cronbach Alpha reliability co-efficient is .74; The Speaking and Grammar Based Methods have three items and their Cronbach Alpha reliability co-efficient is .64. Also it was defined that the Cronbach Alpha reliability co-efficient of the whole scale was 0.89. Total point computation was not carried out in this scale. Each factor was considered as a sub-scale.

\subsection{Data Collection}

After permission was obtained from the Provincial Management of National Education in the city of Duzce, the Language Teaching Methods Scale was filled in by 95 English teachers who worked in secondary schools in Duzce in the 2013-2014 academic year. The scale was given by the researcher to teachers who worked at schools in the city centre and the scale was sent by the District Public Education with an official letter to teachers who worked at schools in the districts.

\subsection{Analysis of Data}

The scale developed by the researcher was used to define the language teaching methods that teachers used. Oxford (1990) evaluated the Scale of Language Learning Strategies in three sections: high level strategy use (3.50-5.00), middle level strategy use (2.50-3.49) and low level strategy use (1.00-2.49), considering the average of answers. In this research, the scale was also evaluated in three sections: high level method use (3.50-5.00), middle level method use (2.50-3.49) and low level method use (1.00-2.49). Tests of normality were done before starting the analysis. The results of the tests are shown in Table 1.

Table 1 . Tests of Normality

\begin{tabular}{|c|c|c|c|c|c|c|}
\hline & \multicolumn{3}{|c|}{ Kolmogrov-Smirnov } & \multicolumn{3}{|c|}{ Shapiro-Wilk } \\
\hline & Statistic & sd & $\mathbf{P}$ & Statistic & sd & $\mathbf{p}$ \\
\hline TEOG 1 & .143 & 95 & .000 & .832 & 95 & .000 \\
\hline TEOG 2 & .119 & 95 & .000 & .919 & 95 & .000 \\
\hline Active Teaching Method & .250 & 93 & .000 & .597 & 93 & .000 \\
\hline Listening Based Teaching Method & .200 & 93 & .000 & .922 & 93 & .000 \\
\hline Four Basic Skills Focused Method & .323 & 93 & .000 & .696 & 93 & .000 \\
\hline Speaking Based Method & .285 & 93 & .000 & .867 & 93 & .000 \\
\hline Grammar Based Method & .375 & 93 & .000 & .486 & 93 & .000 \\
\hline Used Method & .438 & 93 & .000 & .622 & 93 & .000 \\
\hline
\end{tabular}

If " $n$ " is 30 or over, the Kolmogrov-Smirnov test should be carried out in a test of normality (Seçer, 2013). The "p" 
value should be above .050 to understand if distribution is normal. According to this, when we look at Table 1 , we see that the test result is $\mathrm{p}=.000$ for all variables. As there were non-normally distributed data, Spearman's rank order coefficient of correlation was applied to define if there is a relationship between methods used by English teachers and the TEOG foreign language success scores. The Spearman rank order coefficient of correlation is a useful non-parametric test and so can be used when the data have violated parametric assumptions, such as non-normally distributed data (Cokluk, Sekercioglu \& Buyukozturk, 2014; Field, 2009; Seçer, 2013; Singh, 2006). If variables are discontinuous and ordinal, the Spearman rank order coefficient of correlation is useful (Seçer, 2013; Singh, 2006). The Kruskal-Wallis test was also applied to define if there was a statistically significant difference in the students' TEOG foreign language exam scores, depending on the language teaching methods.

\section{Results}

\subsection{Results of the First Sub-problem}

In this section, the first sub-problem is answered is there a relationship between the methods used by English teachers and TEOG foreign language exam success scores? TEOG is given to students twice a year so in this research, both of the exam results were used. They are named as TEOG1 and TEOG2. Spearman's rank order coefficient of correlation was applied to define the relationship between methods and results of TEOG1 and 2. Numerical data about the high level use of methods is presented in Table 2.

Table 2. Numerical Data about High Level of Use of Language Teaching Methods

\begin{tabular}{lll}
\hline & n & \% \\
\hline Grammar Based Method & 20 & 21 \\
Grammar and Four Basic Skills Focused Methods & 72 & 76 \\
Active and Four Basic Skills Focused Methods & 3 & 3 \\
\hline Total & $\mathbf{9 5}$ & $\mathbf{1 0 0}$ \\
\hline
\end{tabular}

As in Table 2, it can be seen that the Grammar Based Method was used at a high level by $21 \%$ of teachers, the Grammar Based Method and Four Basic Skills Focused Method were used together at a high level by $72 \%$ of teachers and the Active Method and Four Basic Skills Focused Method were used together at a high level by 3\% of teachers. The Speaking Based Method and Listening Based Teaching Method were not used by the teachers. The relationship between methods and TEOG are presented below.

Table 3. Relationship between the Grammar Based Method and TEOG 1 and TEOG 2

\begin{tabular}{|c|c|c|c|c|}
\hline & $\begin{array}{l}\text { Grammar } \\
\text { Method }\end{array}$ & Based & TEOG 1 & TEOG 2 \\
\hline Grammar Based Method & 1 & & & \\
\hline TEOG 1 & $.561 * *$ & & 1 & \\
\hline TEOG 2 & $.702 * *$ & & $.769 * *$ & 1 \\
\hline
\end{tabular}

The Spearman rank correlation was applied to define whether there was relationship between the Grammar Based Method and TEOG 1 and TEOG 2. It was found that there was a positive and meaningful relationship between method and both TEOG 1 (rho:.561, p<.01) and TEOG 2 (rho:.702, p<.01).

Table 4. Relationship between Grammar and Four Basic Skills Focused Methods and TEOG 1 and TEOG 2

\begin{tabular}{|c|c|c|c|}
\hline & $\begin{array}{l}\text { Grammar and Four } \\
\text { Basic Skills Focused Methods }\end{array}$ & TEOG 1 & TEOG 2 \\
\hline $\begin{array}{l}\text { Grammar and Four Basic Skills Focused } \\
\text { Methods }\end{array}$ & 1 & & \\
\hline TEOG 1 & $.580 * *$ & 1 & \\
\hline TEOG 2 & $.616 * *$ & $.769 * *$ & 1 \\
\hline
\end{tabular}

The Spearman rank correlation was carried out to define whether there was relationship between the Grammar and Four Basic Skills Focused Methods and TEOG 1 and TEOG 2. As a result, it was found that there was a positive and meaningful relationship between method and both TEOG 1 (rho:.692, p<.01) and TEOG 2 (rho:.796, p<.01).

Table 5. Relationship between Active and Four Basic Skills Focused Methods and TEOG 1 and TEOG 2

\begin{tabular}{lllc}
\hline & $\begin{array}{l}\text { Active and Four Basic Skills } \\
\text { Focused Methods }\end{array}$ & TEOG 1 & TEOG 2 \\
\hline Active and Four Basic Skills Focused Methods & 1 & & \\
TEOG 1 & $.692^{* *}$ & 1 & $.769^{* *}$ \\
TEOG 2 & $.796^{* *}$ & 1 \\
\hline
\end{tabular}

The Spearman rank correlation was done to define whether there was a relationship between Active and Four Basic Skills Focused Methods and TEOG 1 and TEOG 2. As a result, it was found that there was a positive and meaningful relationship between method and both TEOG 1 (rho:.692, p<.01) and TEOG 2 (rho:.796, p<.01). 


\subsection{Results of Second Sub-problem}

In this section, the second sub-problem is answered: is there a statistically significant difference in students' TEOG foreign language exam scores depending on the language teaching methods used by their English teachers? The Kruskal Wallis test was carried out to define whether students' successes changed according to the methods used at a high level. The difference between success and method used at high level is presented in Table 6 .

Table 6. The Result of Kruskal Wallis Test onTEOG1Exam Scores in Terms of Method Used at High Level

\begin{tabular}{llllll}
\hline & n & Mean Rank & sd & $\boldsymbol{X}^{2}$ & P \\
\hline Grammar Based Method & 20 & 18.20 & 2 & 35.056 & .000 \\
$\begin{array}{l}\text { Grammar and Four Basic } \\
\text { Skills Focused Methods }\end{array}$ & 72 & 54.43 & & & \\
$\begin{array}{l}\text { Active and Four Basic Skills } \\
\text { Focused Methods }\end{array}$ & 3 & 92.33 & & & \\
\hline
\end{tabular}

The Kruskal Wallis test was done to define whether there was a meaningful difference between the TEOG 1 exam score and the methods used at a high level. It was found that there was a significant difference $\left(X^{2}: 35.056, \mathrm{sd}: 2, \mathrm{n}: 95, \mathrm{p}>.05\right)$. According to this, it can be said that success in the TEOG 1 exam scores was affected by the method used. As a result of the test, it was found that the students whose teachers used Active and Four Basic Skills Focused Methods together had higher scores in the TEOG 1 English exam than students taught with Grammar Based Method, and Grammar and Four Basic Skills Focused Methods together. We can say when the Active Method and Four Basic Skills Focused Method are used together, it is more successful than when the Grammar Based Method and Grammar and Four Basic Skills Focused Methods are used.

Table 7. The Result of the Kruskal Wallis Test onTEOG2 Exam Score in Terms of Method Used at High Level

\begin{tabular}{|c|c|c|c|c|c|c|}
\hline & & $\mathbf{n}$ & Mean Rank & Sd & $X^{2}$ & $\mathbf{P}$ \\
\hline Grammar Based Method & & 20 & 10.75 & & & \\
\hline $\begin{array}{l}\text { Grammar and Four } \\
\text { Skills Focused Methods }\end{array}$ & Basic & 72 & 56.47 & 2 & 51.318 & .000 \\
\hline $\begin{array}{l}\text { Active and Four Basic } \\
\text { Focused Methods }\end{array}$ & Skills & 3 & 93.00 & & & \\
\hline
\end{tabular}

The Kruskal Wallis test was done to define whether there is a meaningful difference between TEOG 1 exam score and methods used at a high level. It was found that there was a significant difference $\left(X^{2}: 51.318, \mathrm{sd}: 2, \mathrm{n}: 95, \mathrm{p}>.05\right)$. According to this, it can be said that the success of TEOG 2 exam scores were affected by the method used. As a result of the test, it was found that the students whose teachers used Active and Four Basic Skills Focused Methods together had higher scores in the TEOG 2 English exam than students taught with Grammar Based Method and Grammar and Four Basic Skills Focused Methods together. We can say when the Active Method and Four Basic Skills Focused Method are used to gather, it is more successful than when the Grammar Based Method, and Grammar and Four Basic Skills Focused Methods are used.

\section{Conclusion}

\subsection{Conclusion about First Sub-problem}

In the first sub-problem, we aimed to see whether there was a relationship between TEOG and methods used by the teachers. We can say that there was a positive and meaningful relationship between language teaching methods and the results of TEOG1 and TEOG2. Teachers have an important function in an effective teaching and learning process, taking an active role from planning to implementation. In this context, teachers' strategies, methods and techniques become important (Taspinar \& Atici, 2002). Teaching methods involve teachers' implementation of tasks to accomplish the objectives. In other words, methods mean using materials and techniques and organizing them (Clark \& Starr, 1981).

Doymus, Simsek, and Bayrakceken (2004) researched the effect of teaching methods on exam scores. In their research, the effect of traditional and cooperative learning methods on exam scores in science was studied. They found that students using cooperative learning were more successful than students using traditional learning methods. Bozkurt and Aydogdu (2009) researched the effect of traditional and the Dunn and Dunn Learning style on academic success. As a result of the analysis, it was found that methods did affect success, and students who learned through the Dunn and Dunn Learning style had higher scores than the class that was taught with traditional learning methods. Bas (2010) researched the effect of the Learning Based on Brain Method on success in English and attitude toward English. It was found that attitude and success in the class using the Learning Based on Brain Method were higher than the class that was taught with traditional methods. In this context, it is obvious that methods do affect success and teachers should use effective methods to accomplish the objectives. 


\subsection{Conclusion about Second Sub-problem}

In the second sub-problem, we aimed to see if there was a statistically significant difference in students' TEOG foreign language exam scores depending on the language teaching methods used by their English teachers. As a result of the analysis, it was found that there was a statistically significant difference in students' TEOG foreign language exam scores depending on the language teaching methods used by their English teachers. According to the analysis, students who were taught through the Active Method and Four Basic Skills Focused Method together had a higher score in the TEOG English exam than students who were taught through the Grammar Based Method and Grammar and Four Basic Skills Focused Methods. As the number of teachers using the Active and Four Basic Skills Focused Methods together was low, it may be thought that the data were insufficient to make a comparison. However, when we looked at the scores, we saw that the students who were taught through the Active Method and Four Basic Skills Focused Method together had a higher score in the TEOG English exam than other students. It was found that the students who were taught through the Grammar Based Method had scores of 45 and under, students who were taught through the Grammar and Four Basic Skills Focused Methods together had scores of 45 to 70, and students who were taught through the Active and Four Basic Skills Focused Methods together had scores of 70 and over. This result supports Hisar (2006), and Ozbay and Akdag's (2013) studies. Hisar (2006) carried out some experimental research and taught English with a traditional method in a control group and taught English with different methods making the learner active in an experimental group for a year. At the end of the year, he found that there were differences between the classes in favor of the experimental group. The students in the experimental group had higher scores in the exams than the others. Ozbay and Akdag (2013) observed the effect of active learning on learning idioms and as a result, they found that active learning was effective and provided permanent learning.

We can see that in Turkey most teachers preferred to use the Grammar Based Method, but in the TEOG English exam, speaking, listening and writing skills are not tested, it is a multiple choice test. This research shows that, although teachers prefer the Grammar Based Method thinking along this kind of examination system, students who were taught through the Active Method and Four Basic Skills Focused Method together are more successful than the others. In fact, when TEOG is observed, it is seen that TEOG does not examine only grammar knowledge, it involves reading texts and dialogues. As the curriculum suggests, if grammar is taught in a context and speaking, listening, reading and writing skills are focused, students can achieve higher exam scores and acquire speaking and listening skills.

\section{References}

Ansin, S. (2006). Cocuklarda yabancı dil Ogretimi.D.U.Ziya Gokalp Egitim Fakultesi Dergisi, 6, 9-20.

Bas, G. (2010). Beyin Temelli Ogrenme Yonteminin Ingilizce Dersinde Ogrencilerin Erisilerine Ve Derse Yonelik Tutumlarina Etkisi. Ilkogretim Online, 9(2), 488-507. Retrieved from http://dergipark.ulakbim.gov.tr/ilkonline/article/view/5000038052/5000036909

Bozkurt, O., \& Aydogdu, M. (2009). Ilköğretim 6. Sınıf Fen Bilgisi Dersinde Dunn ve Dunn Ogrenme Stili Modeline Dayali Ogretim ile Geleneksel Ogretim Yonteminin Ogrencilerin Akademik Basari Duzeyleri ve TutumlarinaEtkisinin Karsilastirilmasi. Ilkogretim Online, 8(3), 741-754. Retrieved from http://dergipark.ulakbim.gov.tr/ilkonline/article/view/5000038129/5000036986

Buyukozturk, S., Cakmak, E. K., Akgun, O. E., Karadeniz, S., \& Demirel, F. (2013). Bilimsel Arastirma Yontemleri. Ankara: Pegem Akademi.

Clark, L. H., \& Starr, I. S. (1981). Secondary and middle school teaching method. New York, NY: MacMillan Publishing Co.

Cokluk, O., Sekercioglu, G., \& Buyukozturk, S. (2014). Sosyal Bilimler için Cok Degiskenli Istatistik SPSS ve LISREL Uygulamalari. Ankara: Pegem Akademi.

Demirel, O. (2012). Yabancı Dil Öğretimi. Ankara: Pegem Akademi.

Doymus, K., Simsek, U., \& Bayrakceken, S. (2004). Işbirlikçi Ogrenme Yönteminin Fen Bilgisi Dersinde Akademik Basari ve Tutuma Etkisi. Turk Fen Egitimi Dergisi, 1(2).

Field, A. (2009). Discovering statistics using SPSS. (3rd ed.). SAGE Publications.

Gomleksiz, M. N., \& Elaldı, S. (2011). Yapilandirmaci Yaklaşim Bağlamında Yabanci Dil Ogretimi. Turkish Studies-International Periodical for the Languages, Literature and History of Turkishor Turkic, 6(2), 443-454. Retrieved from http://egitim.erciyes.edu.tr/ arak/3.TurkceOgreniyorum.com/2731Ocak2014TR_EgiticilerSemineri/Makaleler/Yap ilandirmaciYaklasimBaglamindaYabanciDilOgretimi.pdf

Gunes, F. (2011). Dil Ogretim Yaklaşimlari ve Turkce Ogretimindeki Uygulamalar. Mustafa Kemal Universitesi Sosyal 
Bilimler Enstitusu Dergisi, 8(15), 123-148.

Hisar, S. G. (2006). 4. v4 5. Sinıf Ingilizce Derslerinde Kullanılabilecek Etkili Ogretim Yontemleri Uzerine Deneysel Bir Calisma (Master'sthesis). Suleyman Demirel University, Instiute of Social Sciences, Isparta, Turkey.

Isik, A. (2008). Yabanci Dil Egitimimizdeki Yanlislar Nereden Kaynaklaniyor? Journal of Language and Linguistic Studies, 4(2).

Kamhuber, P. (2010). Comparison of grammar in Austrian and Spanish English language teaching textbooks. Vienna: Lehramt Englisch, Bewegungund Sport.

Memis, M. R., \& Erdem, M. D. (2013). Yabancı Dil Ogretimde Kullanilan Yontemler, Kullanim Ozellikleri ve Elestiriler. Turkish Studies-International Periodical for the Languages, Literature and History of Turkishor Turkic, 8(9), 297-318. Retrieved from http://www.turkishstudies.net/Makaleler/321673399_026Memi\%c5\%9fMuhammetRa\%c5\%9fit-vd-297-318.pdf

Murcia, M. C. (2013). Language teaching methods from Greeks to Gattegno. MEXTESOL Journal 37(2), 1-9.

Okmen, B. (2015). Ingilizce Ogretmenlerinin Kullandlklari Dil Ogretim Yontemlerinin Ogrencilerin Akademik Başarısına Etkisi (Master's Thesis). Duzce University, Duzce.

Oxford, R. L. (1990). Language learning strategies: What every teacher should know. Boston MA: Heinle and Heinle.

Ozbay, M., \& Akdag, E. (2013). Deyimlerin Ogretiminde AktifOgrenmenin Etkisi. Ana Dili Egitimi Dergisi, 1(2), 46-54.

Secer, I. (2013). SPSS ve LISREL ile Pratik Veri Analizi. Ankara: Anı Yayincilik.

SETA (Foundation of Politics, Economy and Society). (2012). Turkiye'nin Gençlik Profili. Ankara: SetaYayinlari.

Singh, Y. K. (2006). Fundamentals of research methodology and statistics. New Delhi: New Age International (P) Ltd.

Taspinar, M., \& Atıc1, B. (2002). Ogretim Model, Strateji, Yontem ve Becerileri/Teknikleri: Kavramsal Boyut. Egitim Araştırmalart, 2(8), 207-215.

Yildizlar, M. (2013). Ogretim Ilke ve Yontemleri (4th ed.). Ankara: Pegem Akademi.

\section{(oc) BY}

This work is licensed under a Creative Commons Attribution 3.0 License. 